\title{
The Influence of Turnout and Constituency Diversity on Voting in Southern State House Races in the 1990s
}

\author{
Joseph A. Aistrup
}

This research focuses on assessing the impact of participation on voting in southern state legislative elections in the 1990s. While turnout is the subject of much study as a dependent variable (Hill and Leighley 1999; Bullock, Gaddie, and Kuzenski 1995; Weber 2000, 233-246; Gaddie and Bullock 1997; Davidson 1994; Hogan 1999), its relationship to southern state legislative outcomes has not been extensively studied. I find that higher levels of turnout lead to increased votes for the Republicans. While this was the case only in South Carolina in the early 1990s, by the late 1990s, this pattern was consistent across five of the ten states under study. These findings suggest that the relationship between participation and voting in state legislative elections in the South may be becoming similar to congressional elections (Campbell 1996).

This study also focuses on the influences of constituency diversity on voting outcomes at the state house level. In recent years, most of the discussion regarding the influences of constituency characteristics has been centered around assessing the impact of creating numerous majority-minority districts during the 1990s redistricting (see Lublin and Voss 2000). This study moves beyond this debate to assess the influence of constituency diversity on aggregate voting outcomes, beyond majorityminority districts. Using a measure of constituency diversity (based on the work of William Koetzle (1998)), which measures the "political diversity" of districts, the findings support the contention that constituency diversity has a significant influence in structuring aggregate voting outcomes.

\section{Introduction}

Southern Republican efforts to build their party base reached a crescendo in the 1994 elections. A confluence of issues, strategic politicians, and electoral conditions propelled southern Republicans beyond any previous gains and clearly established the Republicans as more than just a competitor for presidential, statewide, and congressional contests. Today, Republicans (GOP) have a firm foundation in most southern states, and they strongly compete for control of state legislatures. During the 1990s, the Republicans in Virginia, North Carolina, South Carolina, Texas, and Tennessee gained control (for at least one session) of one or both of their state legislative chambers.

This research focuses on assessing the impact of participation on voting in southern state legislative elections in the 1990s. While turnout, as a dependent variable, is the subject of much study (Hill and Leighley 1999;

JosePh A. AISTRUP is Professor of Political Science, Kansas State University.

The American Review of Politics, Vol. 23, Summer, 2002: 141-166

(C)2002 The American Review of Politics 
Bullock, Gaddie, and Kuzenski 1995; Weber 2000, 233-46; Gaddie and Bullock 1997; Davidson 1994; Hogan 1999), the manner in which turnout affects southern state legislative outcomes has not been extensively studied. Research at the Congressional level suggests that because Democrats tend to be elected from low turnout, uncompetitive districts, while Republicans are elected from high turnout, competitive districts, that Republicans must amass considerably more votes to elect the same number of representatives as Democrats. James Campbell argues that this means that Republican votes are being wasted (1996).

This study also focuses on the influences of constituency diversity on voting outcomes at the state house level. In recent years, most of the discussion regarding the influences of constituency characteristics has been centered around assessing the impact of creating numerous majorityminority districts during the 1990s redistricting. Hotly debated among academics, the press, and in court (see Lublin and Voss 2000 for a review of these studies), most research supports the contention that the GOP benefitted from the creation of majority-minority districts. This study moves beyond this debate to assess the influence of constituency diversity on aggregate voting outcomes, beyond majority-minority districts.

The findings show that higher levels of turnout lead to decreased votes for Democrats. While this was the case only in South Carolina in the early 1990 s, by the late 1990s, this pattern was consistent across five of the ten states under study. These findings suggest that relationship between participation and voting in state legislative elections in the South may be becoming similar to congressional elections (Campbell 1996). In addition, using a measure of constituency diversity (based on the work of William Koetzle (1998)), which measures the "political diversity" of districts, the findings support the contention that constituency diversity has a significant influence in structuring aggregate voting outcomes.

\section{Racial Redistricting and Rise of Cheap Seats}

Recent research on southern congressional and state legislative elections has focused on the effects of racial redistricting in the South (see Lublin and Voss 2000; Grofman and Handley 1998; Weber 2000; Gaddie and Bullock 1997; Petrocik and Desposato 1998; Hill 1995). While most analysts agree that raced-based redistricting helped the GOP win U.S. House seats, the magnitude of this effect has been a subject of controversy. For state legislative contests, Lublin and Voss (2000) have convincingly shown that racial redistricting did aid the GOP in most of the lower chambers in the South. However, the lion's share of the net increases in GOP lower house 
representation was due to "realignment effects" as opposed to redistricting effects. The Lublin and Voss study provides an important contribution to understanding of southern politics. Moreover, their study raises many questions regarding the characteristics of groups who realigned to support GOP candidates and the factors that facilitated the variance in realignment effects across states.

Racial-redistricting is important for this research because it sets the framework for assessing the influence of turnout and constituency diversity on electoral outcomes. Table 1 (reprinted from Lublin and Voss 2000, 804) shows the change in the racial composition of state house seats between the 1980s and 1990s redistricting plans. In each state there is a consistent pattern: Additional majority-minority districts are created, while districts with between 20 to 50 percent African-Americans and Latinos are reduced. On the other hand, in every state except Mississippi, the number of districts with less than 10 percent African-Americans are increased. In Mississippi, the gains in seats are concentrated in the 10 to 20 percent black districts.

Table 2 shows the relationship between contested elections and the racial/ethnic composition of state house districts in the 1990s in Alabama, Arkansas, Florida, Georgia, Louisiana, Mississippi, North Carolina, South Carolina, Tennessee, Texas, and Virginia, combined. With Democrats firmly in control of these majority-minority seats, turnout becomes a moot point in many districts. In every election period, Republicans failed to contest over 65 percent of seats in districts with over 40 percent minorities. In the words of James E. Campbell (1996), these are the "cheap seats."

Also apparent are the new opportunities created for the GOP by concentrating blacks into a limited number of districts. The most significant trend is toward the GOP developing its own set of cheap seats. Whereas in 1991-1992, Democrats did not contest 15 percent of seats, by 1997-1998 the Democrats failed to contest 28 percent of seats. Table 2 clearly shows that the GOP developed its advantage in districts with between 0 and 20 percent minorities. Of the 307 districts with only a Republican candidate in 19971998, 251 (82\%) were in districts with less than 20 percent minorities.

For each election period, the "Both Parties" row show the demographic context in which turnout can have an impact. Roughly 60 percent of contested elections occur in districts with less than 20 percent minorities. Another 25 percent of contested elections occur in districts with 20 to 40 percent minorities while the remaining 15 percent occur in districts with greater than 40 percent minorities. As Aistrup and Gaddie (1999) show, there has been much "partisan sorting" of southern state legislative seats in the 1990s. 
144 | Joseph A. Aistrup

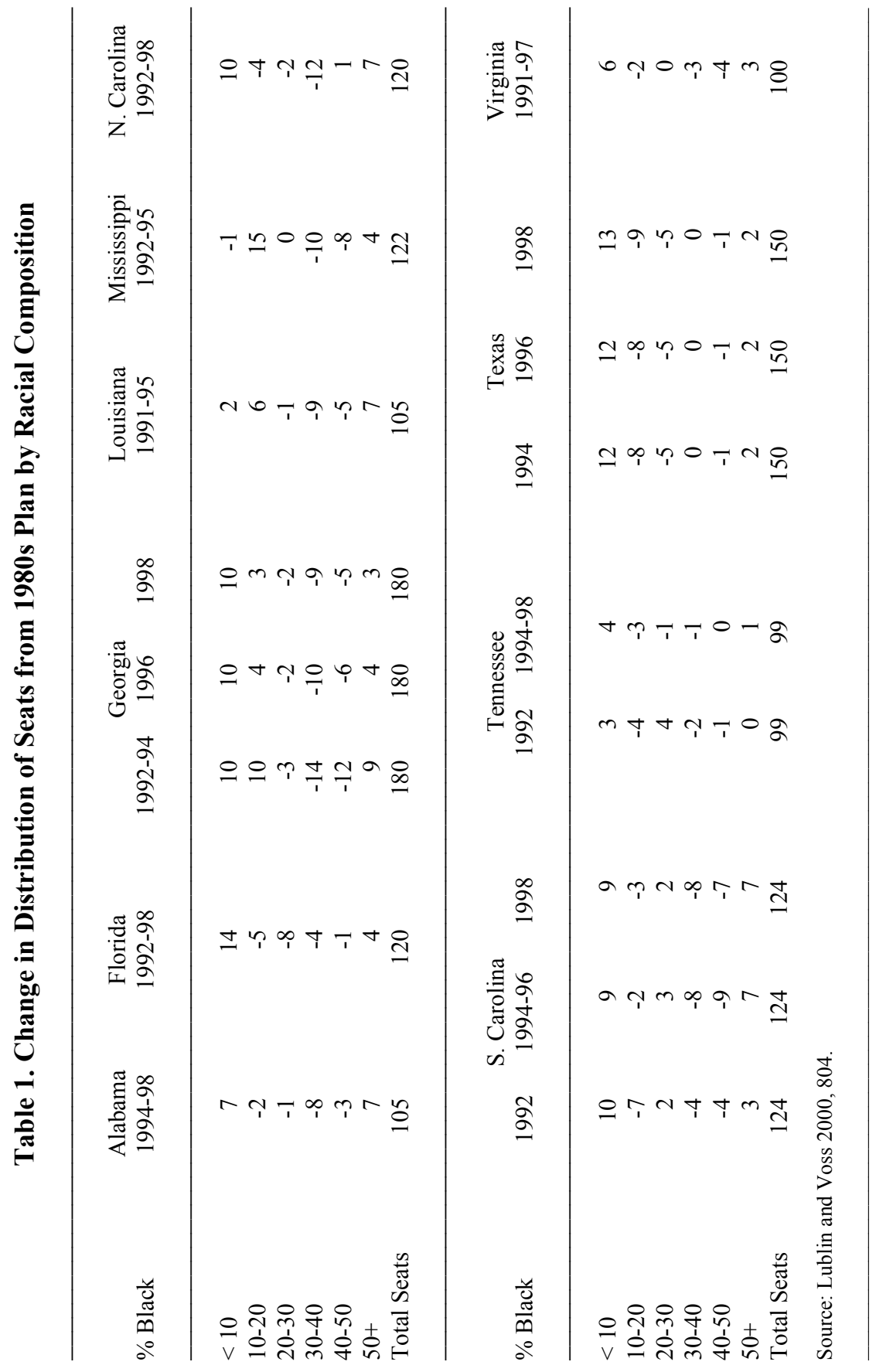


Table 2. The Contesting of State House Districts by the Percent of Minorities, 1991 through 2000

\begin{tabular}{|c|c|c|c|c|}
\hline \multirow{2}{*}{$\begin{array}{l}\text { Contested } \\
\text { State House Districts }\end{array}$} & \multicolumn{4}{|c|}{ Percent of Minorities in State House Districts } \\
\hline & 0 to $20 \%$ & 21 to $40 \%$ & $41 \%$ or Greater & Total \\
\hline \multicolumn{5}{|l|}{ 1991-92 } \\
\hline \multirow[t]{2}{*}{ Republican Only } & 142 & 19 & 10 & 171 \\
\hline & $22.7 \%$ & $7.8 \%$ & $4.1 \%$ & $15.4 \%$ \\
\hline \multirow[t]{2}{*}{ Both Parties } & 316 & 101 & 55 & 472 \\
\hline & $50.5 \%$ & $41.6 \%$ & $22.4 \%$ & $42.4 \%$ \\
\hline \multirow[t]{2}{*}{ Democrat Only } & 168 & 123 & 180 & 471 \\
\hline & $26.8 \%$ & $50.6 \%$ & $73.5 \%$ & $42.3 \%$ \\
\hline \multirow[t]{2}{*}{ Total } & 626 & 243 & 245 & 1114 \\
\hline & $100.0 \%$ & $100.0 \%$ & $100.0 \%$ & $100.0 \%$ \\
\hline \multicolumn{5}{|l|}{ 1993-94 } \\
\hline \multirow[t]{2}{*}{ Republican Only } & 195 & 19 & 8 & 222 \\
\hline & $30.0 \%$ & $8.6 \%$ & $3.5 \%$ & $20.2 \%$ \\
\hline \multirow[t]{2}{*}{ Both Parties } & 311 & 103 & 54 & 468 \\
\hline & $47.9 \%$ & $46.8 \%$ & $23.6 \%$ & $42.6 \%$ \\
\hline \multirow[t]{2}{*}{ Democrat Only } & 143 & 98 & 167 & 408 \\
\hline & $22.0 \%$ & $44.5 \%$ & $72.9 \%$ & $37.2 \%$ \\
\hline \multirow[t]{2}{*}{ Total } & 649 & 220 & 229 & 1098 \\
\hline & $100.0 \%$ & $100.0 \%$ & $100.0 \%$ & $100.0 \%$ \\
\hline \multicolumn{5}{|l|}{$1995-96$} \\
\hline \multirow{2}{*}{ Republican Only } & 200 & 40 & 17 & 257 \\
\hline & $33.2 \%$ & $16.9 \%$ & $6.3 \%$ & $23.2 \%$ \\
\hline \multirow[t]{2}{*}{ Both Parties } & 303 & 133 & 74 & 510 \\
\hline & $50.2 \%$ & $56.4 \%$ & $27.3 \%$ & $45.9 \%$ \\
\hline \multirow[t]{2}{*}{ Democrat Only } & 100 & 63 & 180 & 343 \\
\hline & $16.6 \%$ & $26.7 \%$ & $66.4 \%$ & $30.9 \%$ \\
\hline \multirow[t]{2}{*}{ Total } & 603 & 236 & 271 & 1110 \\
\hline & $100.0 \%$ & $100.0 \%$ & $100.0 \%$ & $100.0 \%$ \\
\hline \multicolumn{5}{|l|}{$1997-98$} \\
\hline \multirow{2}{*}{ Republican Only } & 251 & 41 & 15 & 307 \\
\hline & $40.0 \%$ & $19.1 \%$ & $5.9 \%$ & $28.0 \%$ \\
\hline \multirow[t]{2}{*}{ Both Parties } & 281 & 112 & 64 & 457 \\
\hline & $44.8 \%$ & $52.1 \%$ & $25.1 \%$ & $41.7 \%$ \\
\hline \multirow[t]{2}{*}{ Democrat Only } & 95 & 62 & 176 & 333 \\
\hline & $15.2 \%$ & $28.8 \%$ & $69.0 \%$ & $30.4 \%$ \\
\hline \multirow[t]{2}{*}{ Total } & 627 & 215 & 255 & 1097 \\
\hline & $100.0 \%$ & $100.0 \%$ & $100.0 \%$ & $100.0 \%$ \\
\hline \multicolumn{5}{|l|}{ 1999-2000 } \\
\hline Republican Only & 234 & 39 & 17 & 290 \\
\hline & $38.7 \%$ & $16.5 \%$ & $6.3 \%$ & $26.1 \%$ \\
\hline Both Parties & 269 & 111 & 45 & 425 \\
\hline & $44.5 \%$ & $47.0 \%$ & $16.6 \%$ & $38.3 \%$ \\
\hline Democrat Only & 101 & 86 & 209 & 396 \\
\hline & $16.7 \%$ & $36.4 \%$ & $77.1 \%$ & $35.6 \%$ \\
\hline Total & 604 & 236 & 271 & 1111 \\
\hline & $100.0 \%$ & $100.0 \%$ & $100.0 \%$ & $100.0 \%$ \\
\hline
\end{tabular}


Other demographic characteristics reinforce these racial characteristics in predicting aggregate voting behavior in southern state house elections. Previous studies of aggregate voting behavior in each state show that Republican success is usually associated with more affluent, highly educated, and suburban communities (see Aistrup 1996; Lamis 1988). This suggests that to obtain a full picture of the importance of constituency diversity on aggregate state legislative voting patterns, it is necessary to control for these reinforcing demographic characteristics. Fortunately, William Koetzle (1998, 561) has constructed a viable measure of district level constituency diversity, which he terms political diversity, reflecting the "differential partisan impact" of these characteristics at the Congressional level. This analysis takes advantage of Koetzle's work to construct a district level measure of constituency diversity at the state legislative level.

\section{Turnout in the New South}

V.O. Key's (1949) study of the old South, focused on turnout, or the lack there of, to explain white Democratic dominance of the southern political system. The passage of the Voting Rights Act in 1965 fundamentally altered this dynamic, allowing blacks and Latinos to vote and participate in representational systems that did not intentionally dilute their votes (for a summary of the voting rights laws and litigation see Davidson 1994).

Despite the passage of the Voting Rights Act over 35 years ago, blacks and Latinos generally do not participate at the same rates as whites (Hill and Leighley 1999). Research in the South suggests that black voting rates only match or surpass whites when a black is on the ballot in a competitive race or a racist white like David Duke is running (Bullock, Gaddie, and Kuzenski 1995). While there is evidence in congressional contests that the majority group in a district (whether a black majority or a white majority) participates at higher rates than the minority group in that district (Weber 2000, 233246), the evidence of this in state legislative contests is unclear. Gaddie and Bullock $(1997,49)$ found that the effects of the newly created majorityminority districts on voter turnout were negligible in Louisiana in 1991. Only white voters in newly created majority-minority upper house districts had higher turnout rates. ${ }^{1}$ Turnout rates for blacks and whites in lower house elections were not affected by district type.

As Table 2 shows, majority-minority districts are not heavily contested by the Republicans. The only majority-minority districts that the GOP successfully contests and wins are located in south Florida's Cuban-American communities. When taking this into consideration along with the weak quality of the GOP challenges in most majority-minority districts, it suggests that 
to properly specify the relationship between turnout and voting patterns, it is necessary to control for majority-minority districts.

In those districts which are not majority-minority, there are strong reasons to suspect that the relationship between participation and southern state legislative election outcomes may start to follow patterns similar to the congressional level. In congressional elections, higher levels of turnout are associated with more votes for Republican candidates (Campbell 1996). One reason to expect convergence is that the development of two-party competition may make patterns of southern politics more like those in the rest of the nation. Thus, just as higher levels of turnout are associated with Republican control of U.S. House districts, this pattern may be also emerging at the state legislative level in the South.

For many this may seem counterintuitive because there has been research suggesting that higher turnout rates facilitate the election of Democratic candidates (Petrocik 1987). However, Campbell convincingly shows that Democrats in Congress control a preponderance of districts with low levels of two-party competition and turnout, whereas the GOP's Congressional districts are more competitive with higher levels of turnout. For Campbell, this pattern of turnout means that the GOP must expend or, in his words, "waste" more votes to get its candidates elected.

The realities of turnout in the new South provide another justification for this hypothesis. The success of southern Republicans in the 1990s is partly related to the mobilization of Christian conservatives into the party. President Reagan, and later, presidential hopeful Pat Robertson, led many Christian conservatives to the GOP table (Edsall and Edsall 1992; Clifton 2000,8). The most prominent and active Christian conservative group working to bring Christians into the party is the Christian Coalition. Since the early 1990s, the Christian Coalition has worked to mobilize voters on behalf of Republican candidates. Voter guides, phone banks, and congressional scorecards are its primary tools to accomplish this goal. "In the days preceding the 1994 elections ... the Christian Coalition distributed 35 million voters guides, 17 million congressional scorecards and made telephone calls to 3 million voters" nationwide (Wald 1997, 233, cited in Clifton 2000, 7). In 1996 and 1998, the Coalition continued these efforts, distributing about the same number of voter guides and scorecards. Of course, the strength of the Coalition is in the South, where the Southern Baptist convention and independent Baptist ministries tend to dominate. ${ }^{2}$

Unfortunately, the information to directly test the relationship between Christian conservatives and the mobilization of voters for Republican state legislative candidates is not currently available. Nonetheless, this research is important because it underscores a number of practical as well as 
theoretical reasons to expect that higher participation rates will be associated with Republican voting patterns at the state legislative level.

\section{Other Variables Influencing Votes}

To properly test the influence of turnout and constituency diversity on southern state house elections, it is necessary to control for variables that also have a significant influence on aggregate voting behavior. There is much research documenting the importance of candidate qualities for influencing voting behavior (see Jacobson 1992 for a review of this literature at the congressional level). The strongest and most reliable candidate quality influencing voting behavior is incumbency. Incumbent candidates are not only less likely to be challenged by an opposing party candidate, when facing a challenger, they are less likely to be in a close contest and lose. Previous research on the effects of incumbency on state legislative elections in the South and non-South show that being an incumbent generally translates into "winning big" (Breaux and Jewell 1992, ch 6; Aistrup 1996, 200205).

Another set of contextual factors that might affect state legislative outcomes is associated with each party's campaign efforts, which entails everything from targeting campaign resources to recruiting candidates. Prior to the 1990s, southern Republicans lacked widespread success regarding their campaign efforts. This could be seen most strikingly in their inability to recruit a full slate of candidates for state legislative elections in most southern states (Aistrup 1996). In the 1990s, Republican parties in many states seemed to have crossed a major threshold as Republicans were almost as successful as Democrats in recruiting candidates for state legislative elections (see Table 2).

Within the context of state legislative election outcomes, each party's campaign effort may be an important component for explaining voting patterns. Because of the importance of contesting state legislative elections for southern Republicans, it is used as a proxy representing the extent of a party's campaign effort in a state. ${ }^{3}$ To the extent that a state party is successful in recruiting candidates, it reflects greater campaign effort (Aistrup and Gaddie 1999) as party leaders at the state and local levels are successful in convincing candidates and voters of the value of a party label for winning elections. Thus, candidates who are associated with state parties that show greater campaign effort through contesting a higher proportion of state house districts in an election should garner a higher percentage of the votes. 


\section{Data, Methods, and Hypotheses}

This analysis tests these hypotheses using election returns from 1991 through 2000 for the lower houses of state legislatures in ten of the eleven original Confederate states. These states are Alabama, Arkansas, Georgia, Florida, Mississippi, North Carolina, South Carolina, Tennessee, Texas, and Virginia. ${ }^{4}$ Prior to the 1990 s, the state legislatures in these states continued to be dominated by the Democrats, and thus, despite all the socio-political changes since World War II in the South (see Black and Black 1987), the politics of these state legislatures remained distinctively southern.

State legislative voting data along with racial composition data were obtained from the Secretary of State or the State Board of Elections in each of these states. The Mississippi and Virginia lower house elections occur on odd years. For purposes of this analysis, these odd year elections have been pooled with those occurring in other states on even years. In the 1990s, these odd year elections were generally harbingers of election results in other states in the following year. In addition, state legislative elections in Alabama and Mississippi generally occur every four years instead of every two years like the other states. Texas did not redistrict until after the 1992 election. One state, North Carolina, has concurrent presidential and gubernatorial elections, which may be relevant in terms of exacerbating national political influences (Kazee 1998).

Because of court challenges, some redistricting took place after the 1992 elections in Georgia, South Carolina, Tennessee, and Virginia. While there was some dismantling of majority-minority districts, in almost all the cases, the incumbent legislators were not displaced in the new districts. In these states, the redistricting followed the path of doing what was minimally expected to satisfy court orders. Additional demographic data for each district were obtained in State Legislative Elections: Voting Patterns and Demographics (Barone, Lilley, and DeFranco 1998).

The appendix table describes the dependent and independent variables, the operationalization of these variables, and the expected relationships between the dependent and independent variables. For each election period, the dependent variable is the Democratic proportion of two-party votes. The analysis uses ordinary least squares regression (OLS) to assess the effects of each of the independent variables on the dependent variable. The research design analyzes contested lower state legislative seats in each two-year election period as a singular event. This adds cases to the analysis, allowing a conclusion to be drawn from the analysis across a broader range of states. Because the number of contested seats in some states is relatively small, it 
is difficult to analyze each state's elections separately using multi-variate techniques.

The analysis includes only contested elections because turnout is a moot point in seats that are uncontested by one of the major parties. In fact, states like Florida do not record the votes cast for seats that are uncontested. ${ }^{5}$ Finally, the analysis focuses on each election period because it allows for the identification of on versus off year differences in voting turnout and the identification of trends in the relationships between the dependent and independent variables that may be a function of the conditions surrounding an election period.

Most researchers are familiar with many of the independent variables used in these analyses. Incumbency is operationalized by two dummy variables, one representing Democratic incumbency and the other representing Republican incumbency. Open seat contests are the comparison group. Compared to open seat contests, Democratic incumbency will have a positive effect on the Democratic proportion of two-party votes while Republican incumbency will have a negative effect.

In developing a measure of party campaign effort the focus is on the extent to which each of the state parties is able to recruit a full slate of state legislative candidates for the election in question. A higher percentage of state house seats contested by Republicans in a state should have a negative relationship with the proportion of Democratic two-party votes while a higher percentage of state house seats contested by Democrats in a state should have a positive relationship.

The racial and ethnic composition of each district is measured by two dummy variables. The first dummy variable represents Cuban-American/ Hispanic (Latino) majority-minority districts in Florida, where it is coded 1 if the percent of Latino population in a Florida district is greater than or equal to 50 percent, and 0 for all other districts. This dummy variable should have a negative relationship with the percentage of Democratic two-party votes. The second dummy variable represents all other majority-minority districts across the South. If the percentage of African-American and/or Latino population is greater than or equal to 50 percent, it is coded 1 , otherwise it is coded 0 . This dummy variable should have a positive association with the percentage of Democratic two-party votes. ${ }^{6}$

Also, included in the analyses is a variable measuring district level political diversity. Unlike Sullivan's measure of social diversity (1973), which assesses the probability of one individual interacting with individuals with dissimilar social characteristics, this measure takes into account the various ways in which social characteristics interact to reinforce partisan orientations or interact to cancel each other out. Thus, districts with a large 
proportion of minorities, lower income, and less suburban are more likely to be dominated by Democrats; even though these districts may be considered very socially diverse and according to traditional theories of partisan competition, more likely to have two-party competition. On the other hand, in districts with large proportions of whites, higher income, and more suburban, the Republicans will be more likely to dominate (Koetzle 1998, 567). This district level measure of constituency diversity takes advantage of this knowledge of political cleavages to devise an index of "political diversity" that sums the signed median deviations for the percentage of whites, blacks, suburban population, population with college degrees, and average income in districts. Except for racial data, which were obtained from state officials in each state after each redistricting, the other demographic indicators come from the State Legislative Elections: Voting Patterns and Demographics (Barone, Lilley, and DeFranco 1998). The resulting constituency diversity index represents a continuum of political diversity ranging from the more affluent, upper to middle class, white, suburban districts (positive numbers), to the less affluent, lower to work class, African-American, and non-suburban districts (negative numbers). Given this coding, political diversity should be negatively related to the percentage of Democratic two-party votes. It is important to note that the more these factors cancel each other out, the more two-party competitive the district.

For each election, the participation rate in each state legislative district is measured by adding together the number of votes for the Democratic, Republican, and independent candidates. Assessing the influence of participation rates on the percentage of Democratic votes across the states is a difficult task because the population of the districts varies among states. While standardizing the participation rates (like the ratio of voters to the number of eligible voters in the district, or creating a Z-score for each election in each state) within each state and election period was considered, there are a number of major disadvantages to standardization. Instead, this research design uses a set of ten toggle variables, representing the participation levels in each of the ten states for each election period. ${ }^{7}$ Each state's toggle variable works in the following manner. For each election period, the toggle variable is coded the actual participation level for each of the contested districts in that state, and 0 for contested districts in the other states (see Sayrs 1989, 46-48, also referred to as a "switching model").

Interpretation is straight forward. Each state's participation slope coefficient simply represents the increase or decrease in the percentage of Democratic two-party votes for each increase of one voter participating in a district in that state. ${ }^{8}$ However, because participation levels and district population counts vary across states, the unstandardized slope coefficients for 
each state's toggle variable are not directly comparable. The addition of one voter in Arkansas with regard to an election outcome is not proportional to the addition of one voter in Alabama.

One major advantage of this methodological approach is that it allows for an inspection of the influence of participation on voting within each state and within each election period. Given that Republican Party development is at a different stage in each of these states, it is reasonable to expect that there will be variances in the influence of participation on voting behavior over time and among states. The expectation is that turnout will play the most significant role in determining aggregate voting outcomes in states in which the GOP is most advanced (Florida, North Carolina, South Carolina, Tennessee, Texas, and Virginia).

In addition, this method also controls for variation in the effects of turnout for on versus off year elections. Of course, the 1994 election is particularly important given the large GOP gains. Based on this, an expectation is that the effects of participation on aggregate voting in 1994 will be statistically significant across more states. In addition, given that the Republicans continued to make gains in lower house representation throughout the 1990s, the negative influence of participation on Democratic voting should continue and become more consistent in its effects across more states after 1994.

\section{Analysis}

The regression equation used to test the influence of turnout and constituency diversity on the Democratic percentage of two-party votes is as follows.

$$
\begin{aligned}
\text { DTPV }= & b_{1}+b_{2} \text { DI }+b_{3} R I+B_{4} \text { MajMin }+B_{5} \text { FL-Latino }+b_{6} \text { PolDiv }+ \\
& b_{7} A R+b_{8} A L+b_{9} F L+b_{10} \mathrm{GA}+b_{11} M S+b_{12} \mathrm{NC}+b_{13} \mathrm{SC}+ \\
& b_{14} \mathrm{TN}+b_{15} \mathrm{TX}+\mathrm{b}_{16} \mathrm{VA}+\mathrm{e}
\end{aligned}
$$

where:

DTPV Democratic percentage of the two-party votes

DI Democratic incumbency

RI Republican incumbency

FL-Latino Dummy variable representing majority-minority Latino districts in Florida

MajMin Dummy variable representing all other majority $\backslash$ minority districts

PolDiv Summed signed median deviations for whites, blacks, suburban, income, and college graduates (Koetzle 1999) 
AR Number voting in state house election in Arkansas, 0 when other states

AL Number voting in state house election in Alabama, 0 when other states

FL Number voting in state house election in Florida, 0 when other state

GA Number voting in state house election in Georgia, 0 when other states

MS Number voting in state house election in Mississippi, 0 when other states

NC Number voting in state house election in North Carolina, 0 when other states

SC Number voting in state house election in South Carolina, 0 when other states

TN Number voting in state house election in Tennessee, 0 when other states

TX Number voting in state house election in Texas, 0 when other state

VA Number voting in state house election in Virginia, 0 when other states

To facilitate easy interpretation, each state's slope coefficient for participation is multiplied by 100 . Thus, the reported slope coefficients represent the change in the percentage of Democratic two-party votes for every increase of 100 voters participating.

\section{Participation and Voting}

Table 3 shows a reduced form of the above equation, focusing on the effects of participation on the Democratic percentage of two-party votes, without controlling for candidate qualities, constituency diversity, and party campaign effort. This analysis is instructive because it illustrates the simple relationship between participation and voting. In each election period, a consistent pattern emerges. Higher levels of participation are associated with lower percentages for Democratic candidates. Except for Arkansas and Mississippi in the early election periods of the 1990s, the t-tests for participation in each state are significant and negative.

While this analysis shows the simple negative correlation between participation and Democratic voting in southern state house districts, it does not provide definitive support for the contention that Republican votes are being wasted. However, if effects of participation levels remain significant and 


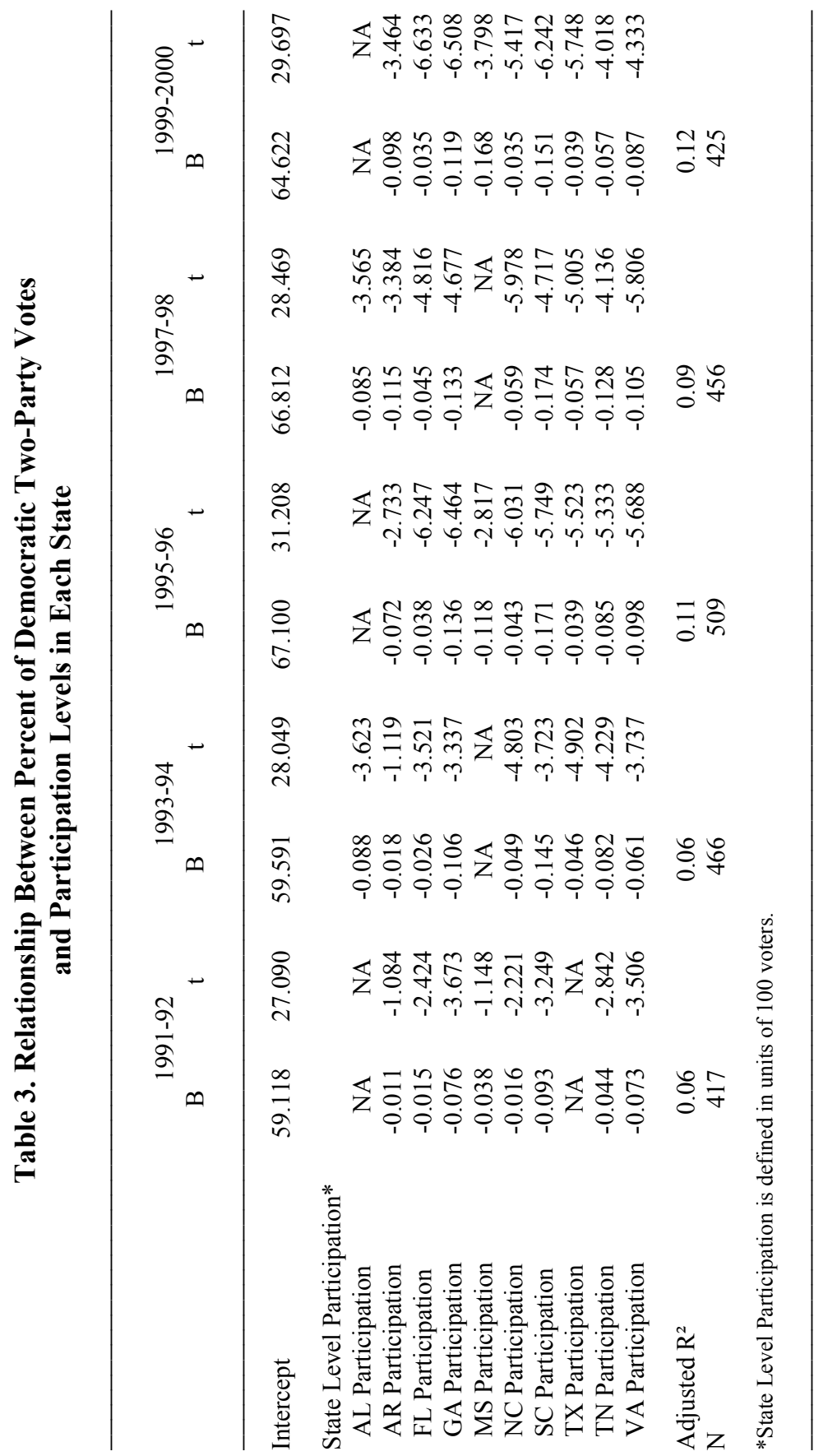


negative after controlling for candidate qualities, constituency diversity, and state party campaign efforts, it would provide some support for the contention that Republican votes are being wasted in Southern state house districts.

For example, take the typical suburban, affluent, largely white district, where the participation is high, and the percentage of Democratic votes is low. In these types of districts, there is strong correlation between the high rate of turnout and the constituent characteristics. To the extent that the high turnout is simply a function of constituency characteristics - that is, affluent people vote at higher rates and for Republicans - then constituency characteristics should explain the lion's share of the variation in voting patterns across districts, and participation rates should have an insignificant relationship with voting. However, if after controlling for constituency characteristics (and the other factors), there remains a significant negative relationship between higher levels of turnout and Democratic voting, it may provide support for the contention that Republican votes are being concentrated into a few districts, and thus, wasted. Of course, the corollary argument is that if these votes were not concentrated, but spread more evenly throughout the district configuration, Republicans would be winning a higher proportion of seats.

\section{Participation, Constituency Diversity, and Wasted Votes (sometimes)}

Table 4 shows the findings from the regression analyses for the full model. Before discussing the impact of turnout and constituency diversity on these voting patterns, there are a number of significant findings related to the control variables.

Candidate Qualities. Democratic and Republican incumbency have significant effect in each period; however, the magnitude of coefficients varies in each election period. From the 1993-1994 period to the 1999-2000 period, the Democratic percentage of two-party votes is eight to 10 percent higher in contests with Democratic incumbents compared to open seat races. However, 1991-1992, the Democratic incumbency advantage was 5.3 percent. The relatively meager impact of Democratic incumbency in 1991-1992 may be a function of Republican tactics in the late 1980s and early 1990s that used voting models to target campaign resources. Thus, in 1991-1992, the GOP contested a smaller number of Democratic incumbents, but many of these Democratic incumbents may have been vulnerable (see Bullock and Schaffer 1997, for a description of the GOP's use of ORVIS to target districts and Democratic incumbents).

On the other hand, the coefficient for Republican incumbency ranges between a low of -8.7 percent in 1999-2000 to a high of -11.4 percent in 
156 | Joseph A. Aistrup

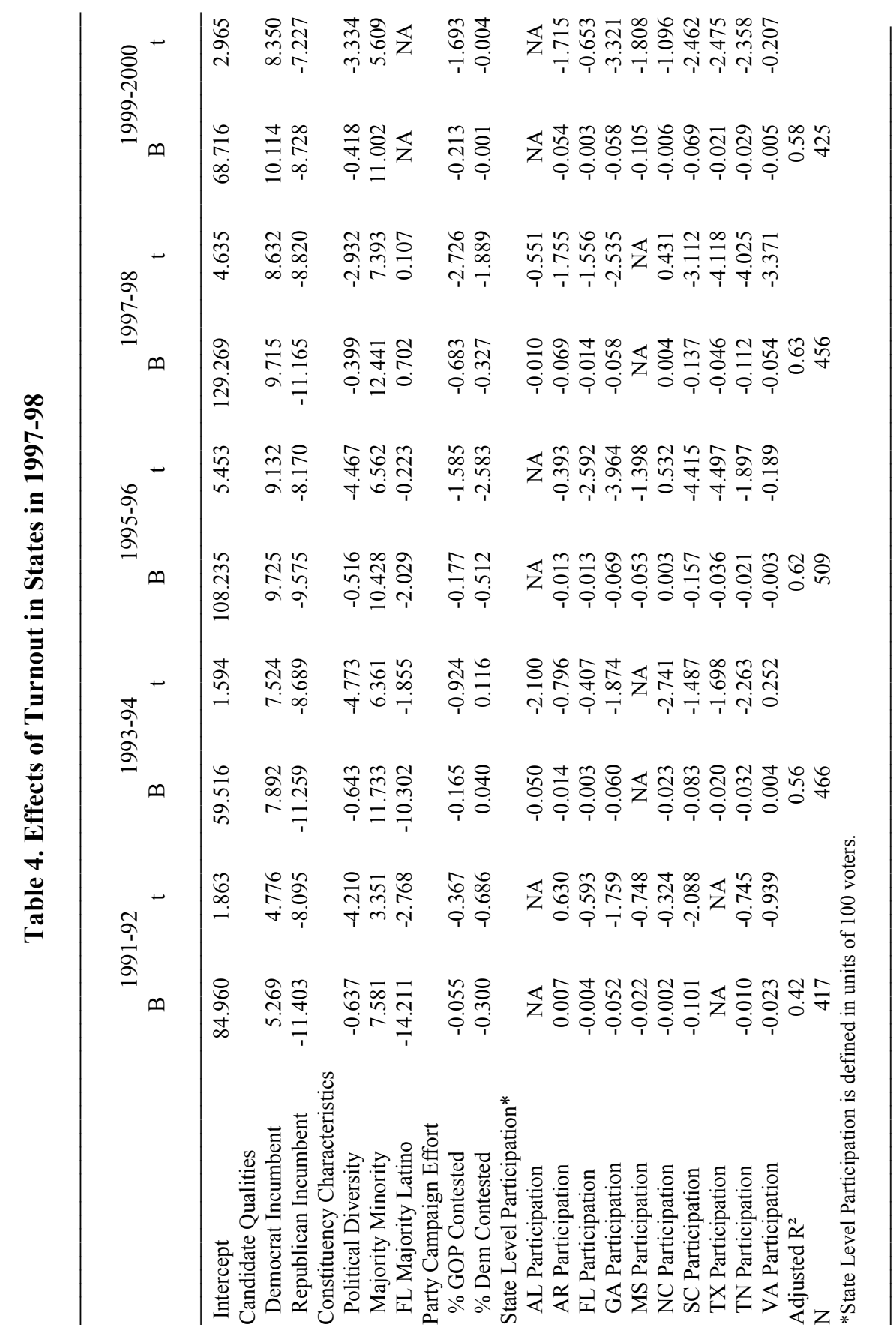


1991-1992. Interestingly, when compared to open seats, in three of the five election periods examined, Republican incumbents appeared to have gained a greater advantage from their incumbency status than Democratic incumbents. Given the large Republican gains in representation made during the 1990s, this finding should not be surprising.

Party Campaign Effort. In three of the five election periods, the coefficients for the percent of Republican contested districts and Democratic contested districts in each state are insignificant. In the 1995-1996 election period, the effect for the percent Democratic contested districts has a negative and significant coefficient (-.512) meaning that for every percent increase in seats contested by Democrats in a state, Democratic votes decreased by .5 percent. This negative relationship is more than likely an artifact of the high proportion of seats contested by southern Democratic parties in an election period when the GOP was winning a larger share of seats than at any other time in the past. Only in 1997-1998, does the percent of seats contested by Republicans have a negative effect on the proportion of Democratic two-party votes (-.683).

Overall, it is important to note that the relationships between party efforts - as represented by the contesting of elections - and voting are not robust. While parties are important for providing a banner for candidates to gravitate toward, once the campaign begins, these contests are largely determined by constituency and candidate characteristics.

Constituency Diversity. As expected, majority-minority districts add significantly to the Democratic share of two-party votes. In every election period, the Democratic share of two-party votes increases by 7.5 to 12 percent for majority-minority districts when compared to non-majority-minority districts. Republicans, on the other hand, benefitted from being in Latinomajority districts in Florida. In these districts, the Democratic share of twoparty votes declined by 14 percent in the 1991-1992 elections. While this effect became insignificant in subsequent election periods, this occurred because of the general lack of Democratic challengers in these Latinomajority districts in Florida. Thus, the overwhelming advantage that Republicans have in these districts dissuades most Democratic challengers.

As expected political diversity has a significant negative relationship with the Democratic share of two-party votes. As noted earlier, more positive values on this index represent a greater number of reinforcing Republican constituency characteristics, whereas negative values represent a greater number of Democratic constituency characteristics. In the first two election periods in the 1990s, the negative effect of political diversity is about -.64. In the 1995-1996 period, this effect is -.52 , while in the last two election periods, the effect declines to the .4 range. This suggests that effects of 
political diversity on voting declined over the decade. One reason for this may be the partisan sorting of districts noted in the first section of this study. After the first two election periods, the new patterns of partisan competition took root in most districts. Just as many Republicans in Latino-majority districts did not face Democratic challengers, many of the districts on both extremes of the political diversity continuum experienced less competition. In addition, as will be discussed below, other factors like participation became more important for explaining the variation in the Democratic percentage of two-party votes.

Participation. As expected, turnout has a negative influence on the Democratic share of two-party votes in a number of states. Of the ten states studied, South Carolina stands out. In every election period except 19931994, higher levels of participation led to Democrats receiving a smaller share of the two-party votes. For example, for every increase of 100 voters in South Carolina's state house contests in 1996, the Democratic percentage of two-party votes decreases by -.16 percent.

One of the major hypotheses regarding the influence of participation on percentage of Democratic votes is that in states where the GOP has experienced more success, Florida, North Carolina, South Carolina, Texas, Tennessee, and Virginia, there is more likely to be a negative relationship. Table 4 shows that there is only partial support for this hypothesis. ${ }^{9}$ In addition to South Carolina, this is the case in three of the election periods for Texas and Tennessee. Of the remaining states where Republicans have made the most substantial inroads, Florida, North Carolina, and Virginia, the negative relationship between participation and voting is statistically significant in only one of the five election periods studied.

Of the remaining states, Georgia shows the most consistent pattern regarding the effects of participation. Starting in 1996, there is a negative relationship between higher levels of participation and the Democratic percentage of two-party votes. This relationship remains statistically significant and negative in last two remaining election periods. Interestingly, while Georgia Republicans have not become the majority party in the state house, the party has made, on a percentage basis, large gains. In 1990, Republicans in Georgia controlled 19 percent of state house seats, but by 1998, they controlled 43 percent. In Arkansas and Mississippi, two states where the Republicans' growth in the 1990s at the state house level is less prominent, the relationship between participation and the percentage of Democratic twoparty votes never achieves statistical significance.

Another expectation was that the effects of turnout on voting would be significant across more states in 1994. This expectation is connected to the hypothesis that after 1994 there would be a more consistent pattern of 
negative relationships between participation and the percentage of Democratic two-party votes across the states. The first expectation received only a modest amount of support. Whereas in 1992, only South Carolina shows a negative relationship (-.101), in 1994, three states have significant negative relationship, Alabama (-.05), North Carolina (-.023), and Tennessee (-.032). Of these three states, the negative relationship for North Carolina may be the most important because control of the lower house changed from the Democrats to the Republicans, but by the slimmest of margins (one seat). However, after the 1993-1994 period, there is a more consistent pattern of negative relationships. In 1995-1996, Florida, Georgia, South Carolina and Texas have significant negative relationships. In 1997-1998, five states have negative relationships, Georgia, South Carolina, Texas, Tennessee and Virginia, while in 1999-2000, four states exhibit negative relationships (Georgia, South Carolina, Texas, and Tennessee). Thus, there is a more persistent pattern of negative relationships between participation in the states and Democratic voting after the 1994 elections.

Discussion. These findings seem to reinforce Campbell's work at the Congressional level. The tables show that in many instances, higher turnout is associated with Republican success. To gain a better picture regarding the impact of participation, the regression coefficients in Table 4 are used to generate the change in the Democratic percentage of two-party votes for the average contested open seat district in 1997-1998 in Georgia, South Carolina, Texas, Tennessee, and Virginia (states for which the participation coefficient is significant). ${ }^{10}$ In examining this average contested district, the analysis focuses on the extent to which typical participation levels in a state change the outcome of state house elections in that state (see Table 5). At the low end of the extreme, the table shows the percent of Democratic votes for a hypothetical district with a participation level that is -1 standard deviation below the mean level of participation for that state. The participation levels are then increased by 2 standard deviation increments until participation levels are +1 standard deviation above the mean level for each state.

Two states standout in this analysis, South Carolina and Texas. When turnout goes from one standard deviation below the mean to one standard deviation above the mean, the Democratic percentage of two-party votes in South Carolina changes by -5.2 percent. In Texas it changes by almost -6 percent. For the other three states, the change in the Democratic percentage of two-party votes is between -3.01 to -4.17 percent.

Significantly, in every state but Georgia, the level of participation plays a key role in determining which party controls the open seat. For South Carolina, the threshold for control is between the mean and +2 standard 
160 | Joseph A. Aistrup

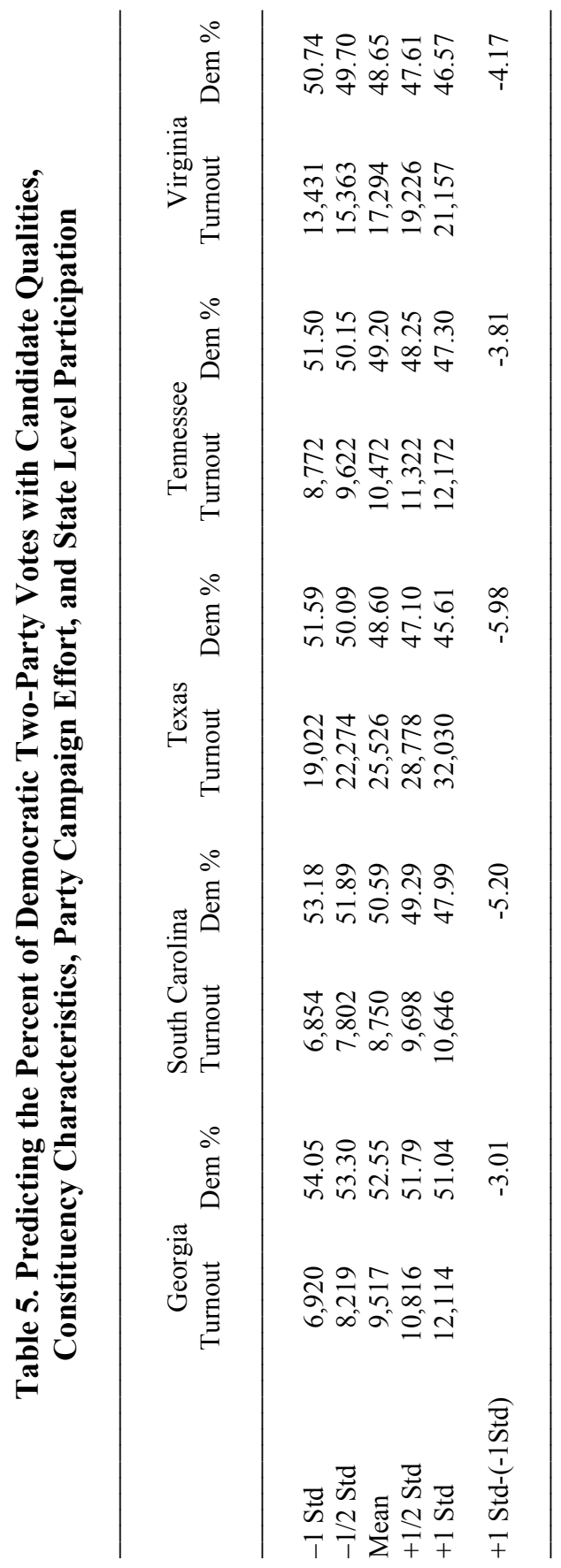


deviation. In Texas and Tennessee, the threshold for control is between the mean and -2 standard deviation. In Virginia, the threshold is between -2 standard deviation and -1 standard deviation. In the case of Georgia, the Democratic percentage remains above 50 percent even at +1 standard deviation above the mean level of participation, but, the open seat contest becomes extremely close (51\%). Together, these analyses suggest that even though the effects of turnout on voting do not seem overwhelming in most states, in open seats and in close races participation levels can be the difference between losing and winning. Thus, these effects are not trivial.

\section{Conclusion}

Increasingly, party competition in the South is focused on a few seats where it is unclear which party has the advantage over the other. While observers of southern politics are accustomed to the GOP failing to field candidates in districts that have a large proportion of minorities, a new development in the 1990s is that the Democrats are not contesting a large proportion of seats in districts dominated by whites. Thus, both parties have their own set of cheap seats where they can reliably field a candidate and win because the other party does not effectively compete for the seat. Two major factors play significant roles in determining where the cheap seats are located, racial composition and incumbency status.

Significantly, constituency characteristics are also important for predicting electoral outcomes. Democrats can expect to garner about 10 percent more votes in majority-minority districts. While this is not surprising, it is significant because it provides a major disincentive for Republican candidacies in majority-minority districts. In addition, the findings show that political diversity plays a major role. The more that social demographic characteristics reinforce one another in favor of the Republicans, the lower the percentage of Democratic votes. This is significant in two respects. First, it underscores the change in southern politics at the local level. Ten to twenty years ago, almost all constituencies elected Democrats, no matter what the level of constituency diversity. In the 1990s, this has clearly changed. Many of the same party cleavage structures that shape the electoral systems in other states are now prevalent in the South. This means that southern politics is becoming less distinctive in terms of the variables that predict election outcomes at the state legislative as well as Congressional levels. Second, these findings underscore the utility of Koetzle's measure of diversity, which focuses on the political implications of constituency characteristics versus the simple probability of interacting with another individual who is socially different (see Sullivan 1973). 
In the seats that are contested in the South, a new dynamic has emerged. The Republicans are now competitive in open seat contests in several southern states. The findings shown in Table 4 indicate that the Democrats are most likely to win in seats where the turnout is below the mean level of turnout. Moving from one standard deviation below the mean level of participation to one standard deviation above the mean level of participation in South Carolina, Texas, Tennessee and Virginia was enough to shift the threshold for a GOP victory in 1998 toward the Republican candidates. In this respect, turnout is a factor that adds an important dimension to this new electoral dynamic.

These findings do correspond with a larger dynamic noted by James Campbell (1996). Just as higher levels of turnout are associated with GOP representation in Congress, so it is also the case for the GOP in eight of the ten Southern states in at least one election. In some states like Georgia, South Carolina, Texas, and Tennessee, this relationship is a consistent feature of the electoral system. This said, one can legitimately ask if this means that Republican votes are being wasted?

The most likely answer is yes. Because this analysis controls for constituency diversity, candidate, and party effort variables, these findings are supportive of Campbell's basic contention that Republican votes are more concentrated within a fewer number of districts and are, thus, being wasted. This suggests that because the GOP must generate higher turnout to get its candidates elected, Democrats benefit from these districts' arrangements. It will be interesting to see if this relationship between turnout and the vote is still prevalent after the 2000 redistricting. Republican control of redistricting in some states may lead to less of a concentration of Republican voters, and thus, to these votes being used more efficiently across a greater number of districts. This may ultimately lead to a greater percentage of Republicans elected.

APPENDIX Variables, Operationalization, and Hypotheses

\begin{tabular}{lll}
\hline Variables & Operationalization & $\begin{array}{l}\text { Hypothesis } \\
\text { with Dependent } \\
\text { Variable }\end{array}$ \\
\hline $\begin{array}{l}\text { Democratic Percentage of } \\
\text { Two-party votes in a Con- } \\
\text { tested State House Districts }\end{array}$ & $\begin{array}{l}\text { Democratic Vote / } \\
\text { (Democratic Vote + Republican Vote) }\end{array}$ & \\
& &
\end{tabular}


APPENDIX (continued)

\begin{tabular}{|c|c|c|}
\hline Variables & Operationalization & $\begin{array}{l}\text { Hypothesis } \\
\text { with Dependent } \\
\text { Variable }\end{array}$ \\
\hline Democratic Incumbency & $\begin{array}{l}\text { Coded } 1 \text { if the candidate is a } \\
\text { Democratic Incumbent, } 0 \text { otherwise }\end{array}$ & $\begin{array}{l}\text { Positive } \\
\text { Relationship }\end{array}$ \\
\hline Republican Incumbency & $\begin{array}{l}\text { Coded } 1 \text { if the candidate is a } \\
\text { Republican Incumbent, } 0 \text { otherwise }\end{array}$ & $\begin{array}{l}\text { Negative } \\
\text { Relationship }\end{array}$ \\
\hline $\begin{array}{l}\text { Majority-Minority } \\
\text { Districts }\end{array}$ & $\begin{array}{l}\text { Coded } 1 \text { if percent African-Americans } \\
\text { for current districting plan } 50 \% \text { or } \\
\text { greater, } 0 \text { otherwise }\end{array}$ & $\begin{array}{l}\text { Positive } \\
\text { Relationship }\end{array}$ \\
\hline $\begin{array}{l}\text { Latino Florida Majority- } \\
\text { Minority Districts }\end{array}$ & $\begin{array}{l}\text { Coded } 1 \text { if percent Latino-Americans } \\
\text { for current districting plan } 50 \% \text { or } \\
\text { greater, } 0 \text { otherwise }\end{array}$ & $\begin{array}{l}\text { Negative } \\
\text { Relationship }\end{array}$ \\
\hline $\begin{array}{l}\text { Percent Contested } \\
\text { Republican }\end{array}$ & $\begin{array}{l}\text { Percent of contested seats by } \\
\text { Democrats in the current election } \\
\text { for each state }\end{array}$ & $\begin{array}{l}\text { Negative } \\
\text { Relationship }\end{array}$ \\
\hline $\begin{array}{l}\text { Percent Contested } \\
\text { Democrat }\end{array}$ & $\begin{array}{l}\text { Percent of contested seats by } \\
\text { Republicans in the current election } \\
\text { for each state }\end{array}$ & $\begin{array}{l}\text { Positive } \\
\text { Relationship }\end{array}$ \\
\hline Political Diversity & $\begin{array}{l}\text { The signed median deviations for } \\
\text { the percent of whites, blacks, college } \\
\text { degrees, suburban, and income } \\
\text { (Barone et al. 1998) }\end{array}$ & $\begin{array}{l}\text { Negative } \\
\text { Relationship }\end{array}$ \\
\hline $\begin{array}{l}\text { Turnout in AR, AL, GA, } \\
\text { MS, NC, SC, TN, TX, } \\
\text { and VA }\end{array}$ & $\begin{array}{l}\text { The sum of Democratic, Republican, } \\
\text { and Independent votes. Toggle vari- } \\
\text { ables coded } 0 \text { for districts in other } \\
\text { states, and the actual participation level } \\
\text { for the state that the variable represents. }\end{array}$ & $\begin{array}{l}\text { Negative } \\
\text { Relationship }\end{array}$ \\
\hline
\end{tabular}

\section{NOTES}

${ }^{1}$ Since Key’s study, many have attempted to measure "white backlash." The most recent work of Lublin and Voss (2000) suggests that there is not strong empirical support for this thesis. While I do not directly test for white backlash, the findings of this study nonetheless support their conclusion.

${ }^{2}$ Moreover, as James Guth (1995) notes, the influence of Christian conservatives in elections goes beyond the Coalition. There are numerous Christian conservatives who are not members of the Coalition, but nonetheless, have begun to vote for Republican 


\section{4 | Joseph A. Aistrup}

candidates. For example, exit polls in the 1994 South Carolina gubernatorial race showed that 80 percent of white, religious right voters supported Republican David Beasley (Guth 1995). Guth's research suggests that with or without the Coalition, Christian conservatives would be mobilizing and supporting southern Republican candidates. Moreover, exit polls suggest that the southern Republicans have found a source of votes as reliable for them as blacks are for the Democrats.

${ }^{3}$ Campaign spending is another option for assessing the impact campaign efforts on state legislative elections. Unfortunately, these data are not readily available for these southern states for the decade. Research by Hogan (1999) suggests that while campaign spending in state legislative races has some impact on turnout, but that constituency factors play a much larger role. In addition, since campaign resources are highly tied to incumbency (Jacobson 1992) and this analysis controls for incumbency, this suggests that the exclusion of campaign spending from this analysis will not bias the findings regarding the influence of turnout and constituency diversity on state legislative voting in these Southern states.

${ }^{4}$ Louisiana's open-primary run-off system represents a fundamentally different election system compared to the other states. Because candidates of the same party can end up running against one-another in the open primary and run-off elections, it is difficult to accurately measure the two-party vote in Louisiana.

${ }^{5}$ These data are not pooled over time because the contesting of seats in each district is sporadic across election cycles. The presence of missing data makes it almost impossible to conduct a pooled cross sections of time series analysis.

${ }^{6}$ Some analysts use the proportion of voting age population who are minority in their analyses. Often, these analyses use ecological regression techniques to estimate the proportion of whites voting for Democratic or Republican candidates (see Weber 2000 for an example). For these studies, using voting age population adds accuracy to their estimation technique. For this study, I am interested in "level effects" of minorities in relationship to the proportion of two-party votes. The proportions of a district's population that are Latino and black accurately represent the possible level effects.

${ }^{7}$ The problems with standardization include obtaining data on the number of eligible voters in each district in each election and interpreting the slope coefficient for a variable that is standardized for each election period within each state.

${ }^{8}$ While this method is similar to dummy variable coding, it is not the same. Because the toggle variables are not coded 1 when toggled on, but are allowed to vary based on participation levels in each district, it is unnecessary to have a comparison state where its districts are always coded 0 .

${ }^{9}$ One factor that could be depressing the relationship between turnout and aggregate Republican voting patterns in these state house districts is the differential participation rates of minority voters in majority-minority districts. The work of Weber (2000) shows that minority turnout is generally enhanced in majority-minority congressional districts. If this finding can also be applied to the state house level, it suggests that in majorityminority districts, higher levels of turnout may be associated with higher levels of Democratic voting.

To test this hypothesis, I tried a number of different approaches, but all to no avail. One approach I tried was to simply add nine new toggle variables representing turnout levels in majority-minority districts in each state. The problem with this approach is that there are only a small number of contested majority-minority districts within each state, 
that it made it difficult to establish causal patterns. In essence, the findings presented in Table 3 were unchanged. The next approach I tried was to standardize the participation variable for each election period within each state. This new participation variable computed a Z-score for turnout in contested seats for each election period in each state, respectively. I then added one more toggle variable to the analysis, representing the standardized turnout rate in majority-minority districts across all nine states under study. The results here were also disappointing. Just as before, the findings did not change from those presented in the earlier section. Higher levels of participation in majority-minority districts did not show a significant relationship with the Democratic proportion of twoparty votes (findings not shown).

${ }^{10}$ For these analyses, majority-minority districts were set to 0 , political diversity was set to equal the average level of political diversity for contested districts in each state, and the Democratic and Republican percentage of seats contested were set to the percentage for each state.

\section{REFERENCES}

Aistrup, Joseph A. 1996. Southern Strategy Revisited. Lexington: University Press of Kentucky.

Aistrup, Joseph A., and Ronald Keith Gaddie. 1999. Candidate Emergence in the New Southern Party System. Paper presented at the annual meeting of the Southern Political Science Association, Savannah.

Barone, Michael, William Lilley III, and Laurence J. DeFranco. 1998. State Legislative Elections: Voting Patterns and Demographics. Washington, DC: CQ Press.

Black, Merle, and Earl Black. 1987. Politics and Society in the South. Cambridge: Harvard University Press.

Breaux, David A., and Malcolm E. Jewell. 1992. Winning Big: The Incumbency Advantage in State Legislative Races. In Changing Patterns in State Legislative Careers, ed. Gary F. Moncreif and Joel A. Thompson. Ann Arbor: The University of Michigan Press.

Bullock, Charles S., III, Ronald Keith Gaddie, and John C. Kuzenski. 1995. The Candidacy of David Duke as a Stimulus for Black Voting. In David Duke and the Rebirth of Race in Southern Politics, ed. John C. Kuzenski, Charles S. Bullock, III, and Ronald Keith Gaddie. Nashville, TN: Vanderbilt University Press.

Bullock, Charles S., III, and David J. Shafer. 1997. Party Targeting and Electoral Success. Legislative Studies Quarterly 22:573-584.

Campbell, James E. 1996. Cheap Seats: The Democratic Party's Advantage in U.S. House Elections. Columbus: Ohio State University Press.

Clifton, Brett M. 2000. Hark! The Religious Right Sings: How Conservative Christians have Influenced the Republican Party. Paper presented at the annual meeting of the American Political Science Association, Washington, DC.

Davidson, Chandler. 1994. The Recent Evolution of Voting Rights Law Affecting Racial and Language Minorities. In Quiet Revolution in the South, ed. Chandler Davidson and Bernard Grofman. Princeton: Princeton University Press. 
Edsall, Thomas B., and Mary D. Edsall. 1992. Chain Reaction. New York: W.W. Norton. Gaddie, Ronald Keith, and Charles S. Bullock, III. 1997. Voter Turnout and Candidate Participation Effects of Affirmative-Action Districting. In Southern Parties and Elections: Studies in Regional Change, ed. Robert P. Steed, Laurence W. Moreland, and Tod A. Baker. Tuscaloosa: University of Alabama Press.

Grofman, Bernard, and Lisa Handley. 1998. Estimating the Impact of Voting-RightsRelated Districting on Democratic Strength in the U.S. House of Representatives. In Race and Redistricting in the 1990s, ed. Bernard Grofman. New York: Agathon Press.

Guth, James L. 1995. South Carolina: The Christian Right Wins One. PS: Political Science and Politics 28:8-12.

Hill, Kevin. 1995. Does the Creation of Majority Black Districts Aid Republicans: An Analysis of the 1992 Congressional Elections in Eight Southern States. Journal of Politics 57:384-401.

Hill, Kim Q., and Jan E. Leighley. 1999. Racial Diversity, Voter Turnout, and Mobilizing Institutions in the United States. American Politics Quarterly 27:275-295.

Hogan, Robert E. 1999. Campaign and Contextual Influences on Voter Participation in State Legislative Elections. American Politics Quarterly 27:403-4 33.

Jacobson, Gary C. 1992. The Politics of Congressional Elections, 3rd ed. New York: HarperCollins.

Kazee, Thomas A. 1998. North Carolina. In The New Politics of the Old South: An Introduction to Southern Politics, ed. Charles S. Bullock, III, and Mark Rozell. Baltimore, MD: Rowman and Littlefield.

Key, V.O., Jr. 1949. Southern Politics in State and Nation. New York: Knopf.

Koetzle, William. 1998. The Impact of Constituency Diversity upon the Competitiveness of U.S. House Elections, 1962-1996. Legislative Research Quarterly 23:561-573.

Lamis, Alexander P. 1988. The Two Party South. New York: Oxford University Press.

Lublin, David, and D. Stephen Voss. 2000. Racial Redistricting and Realignment. American Journal of Political Science 44:792-810.

Petrocik, John. 1987. Voter Turnout and Electoral Preference: The Anomalous Reagan Elections. Pp. 239-260 in Election in America, ed. Kay Lehman Schlozman. Boston: Allen \& Unwin.

Petrocik, John, and Scott W. Desposato. 1998. The Partisan Consequences of MajorityMinority Redistricting in the South, 1992 and 1994. Journal of Politics 60:613-633.

Sayrs, Lois W. 1989. Pooled Time Series Analysis. Newbury Park, CA: SAGE.

Sullivan, John L. 1973. Political Correlates of Social, Economic, and Religious Diversity in American States. Journal of Politics 35:70-84.

Wald, Kenneth D. 1997. Religion and Politics in the United States, 3rd ed. Washington, DC: CQ Press.

Weber, Ronald E. 2000. Race-Based Districting: Does it Help or Hinder Legislative Representation? Political Geography 19:213-247. 